\title{
Removal and transformation of pharmaceuticals in wastewater treatment plants and constructed wetlands
}

\author{
E. Lee ${ }^{1}$, S. Lee ${ }^{2}$, J. Park ${ }^{3}$, Y. Kim ${ }^{4}$, and J. Cho ${ }^{3}$ \\ ${ }^{1}$ Department of Civil, Environmental and Architectural Engineering, University of Colorado Boulder, \\ Boulder, CO 80309, USA \\ ${ }^{2}$ Woongjin Chemical Co., Ltd, KANC 906-10, lui-dong, Yeongtong-gu, Suwon-si, \\ Gyeonggi-do 443-270, Korea \\ ${ }^{3}$ School of Civil and Environmental Engineering, Yonsei University, Yonsei-ro 50, \\ Seodaemun-gu, Seoul 120-749, Korea \\ ${ }^{4}$ Department of Environmental Science and Engineering, Gwangju Institute of Science and Technology (GIST), \\ 1 Oryong-dong, Buk-gu, Gwangju, 500-712, Korea \\ Correspondence to: E. Lee (eunkyung.lee83@gmail.com)
}

Received: 25 March 2013 - Published in Drink. Water Eng. Sci. Discuss.: 2 May 2013

Revised: 26 July 2013 - Accepted: 2 August 2013 - Published: 12 August 2013

\begin{abstract}
Since trace organic compounds such as pharmaceuticals in surface water have been a relevant threat to drinking water supplies, in this study removal of pharmaceuticals and transformation of pharmaceuticals into metabolites were investigated in the main source of micropollutants such as WWTPs and engineered constructed wetlands. Pharmaceuticals were effectively removed by different WWTP processes and wetlands. Pharmaceutical metabolites with relatively low $\log D$ value were resulted in the low removal efficiencies compared to parent compounds with relatively high $\log D$ value, indicating the stability of metabolites. And the constructed wetlands fed with wastewater effluent were encouraged to prevent direct release of micropollutants into surface waters. Among various pharmaceuticals, different transformation pattern of ibuprofen was observed with significant formation of 1-hydroxy-ibuprofen during biological treatment in WWTP, indicating preferential biotransformation of ibuprofen. Lastly, transformation of pharmaceuticals depending on their structural position was investigated in terms of electron density, and, the electron rich $C_{1}=C_{2}$ bond of carbamazepine was revealed as an initial transformation position.
\end{abstract}

\section{Introduction}

For several decades, pharmaceuticals and personal care products (PPCPs) have been noticed as emerging problematic compounds (Ternes et al., 1998; Snyder et al., 2003). In order to reduce residual concentrations of PPCPs, various advance treatments have been studied by many research groups (Lee and Gunten, 2010; Rosal et al., 2010 and many others). However, high levels of PPCPs are still detected in wastewater effluent, surface waters, and drinking waters (Kim et al., 2007; Lee et al., 2012; Yoon et al., 2010; Benotti et al., 2009). Since those trace organic compounds have been detected even in treated drinking waters by Benotti et al. (2009), control of micropollutants has been important especially in the wastew- ater treatment plant, the main source of the micropollutants in the aquatic environments.

Meanwhile, constructed wetlands have been introduced as an alternative to wastewater treatment for micropollutants removal (Matamoros and Bayona, 2006). And few reports have been focused on the relationship between $\log D$ and removal of PPCPs in wetland systems. In previous study (Lee et al., 2011), removal efficiency in constructed wetlands has been investigated using corresponding octanol-water partitioning coefficient of pharmaceuticals.

And few studies have been reported with regarding to behaviors of pharmaceutical metabolites in various environments (Stumpf et al., 1998; Quintana et al., 2005). The 
potential ecotoxicological effect of pharmaceutical metabolites is still not known, thus, there is necessity to study further about the fate of pharmaceutical metabolites in various wastewater treatment processes.

In this study, removal and transformation of pharmaceuticals has been investigated with regarding to physicochemical and structural properties of pharmaceuticals and their metabolites in various environments such as WWTPs and constructed wetlands receiving wastewater effluent.

\section{Materials and methods}

\subsection{Target compounds}

Various micropollutant compounds, including 9 pharmaceuticals, 11 selected metabolites, and 1 personal care product, were selected in this study. Acetaminophen (ACT), atenolol (ATN), carbamazepine (CBZ), diclofenac (DCF), glimepiride (GMP), ibuprofen (IBU), naproxen (NPX), O-desmethyl-naproxen (O-desmethyl-NPX), sulfamethoxazole (SMX), and tri(2-chloroethyl) phosphate (TCEP) were obtained from Sigma-Aldrich (St. Louis, MO). Caffeine (CAF) was purchased via Fluka Chemie GmbH (Buchs, Switzerland). 1-hydroxy ibuprofen (IBU-1OH), 2-hydroxy ibuprofen (IBU-2OH), ibuprofen carboxylic acid (IBU-CA), iopromide (IOP), and $\mathrm{N}$-acetyl-sulfamethoxazole (N-acetyl-SMX), paraxanthine, paraxanthine-1-methyl-d3, 4-hydroxy diclofenac were purchased via Tronto Research Inc (Tronto, Canada). Authentic carbamazepine metabolites 10, 11-dihydro-10, 11epoxycarbamazepine (CBZ-EP), 2-hydroxycarbamazepine (CBZ-2OH), 3-hydroxycarbamazepine (CBZ-3OH), and 10, 11-dihydro-10-hydroxycarbamazepine (CBZ-10OH) were provided from Norvatis Pharma AG (Basel, Switzerland). Carbamazepine- $\mathrm{d}_{10}$ and ${ }^{13} \mathrm{C}_{1}$-naproxen- $\mathrm{d}_{3}$ were purchased from Cambridge Isotope Laboratories (Andover, MA, US). Atenolol- $\mathrm{d}_{7}$ and diclofenac- $\mathrm{d}_{4}$ were obtained from $\mathrm{C} / \mathrm{D} / \mathrm{N}$ Isotopes (Pointe-Claire, Canada). Ibuprofen- $\mathrm{d}_{3}, \mathrm{~N}^{4}-$ acetylsulfamethoxazole- $\mathrm{d}_{4}$, and sulfamethoxazole- $\mathrm{d}_{4}$ were obtained from Tronto Research Inc (Tronto, Canada). HPLC grade methanol was obtained from J.T. Baker (Philipsburg, NJ, US). Methyl tert-butyl ether (MTBE) and formic acid were obtained from Sigma-Aldrich (St. Louis, MO, US). Information of target compounds and their metabolites is listed in Table 1 . The $\log K_{\text {ow }}, \log D_{\text {ow }}$, and $p K_{\mathrm{a}}$ for investigated compounds was calculated based on the molecular structures using ChemAxon Marvin Calculator Plugin. The $\log D_{\text {ow }}$ is a pH dependent $\log K_{\text {ow }}$ value and in this study $\log D$ at $\mathrm{pH} 7$ was used.

\subsection{Sample collection}

In June 2010, water samples were collected from each process (influent and effluents of the various unit operations) in three different wastewater treatment plant. One is Gwangju primary municipal wastewater treatment plant, which is operated with the nitrogen and phosphorus removal treatment system $\left(600000 \mathrm{~m}^{3} \mathrm{day}^{-1}\right)$. Second sampling sites was Gwangju secondary municipal wastewater treatment plant, which had two different treatment trains (Conventional Activated Sludge and Modified Ludzack-Ettinger (MLE) process), having total capacity up to $120000 \mathrm{~m}^{3}$ day $^{-1}$. In those two different Gwangju municipal WWTPs, sodium hypochlorite was added as a disinfectant and final effluent samples were collected after disinfection process. Additionally, water samples from both Damyang wastewater treatment plant and Damyang constructed wetlands were collected and studied. There was no disinfection system in Damyang WWTP and final effluent was collected after secondary treatment. Damyang constructed wetlands connected to Damyang wastewater treatment plant is free surface flow constructed wetlands, which have two different ponds, containing Aporus ponds followed by Typha ponds. The hydraulic retention time of wetlands is approximately $6 \mathrm{~h}$ and flow rate is $1800 \mathrm{~m}^{3}$ day $^{-1}$. Every sample was spiked with a biocide sodium azide and ascorbic acids to quench any residual oxidant in the field.

\subsection{SPE and LC-MS/MS analysis}

After filtration using glass fiber membrane filter, all analytes were extracted by using AutoTrace automated solid phase extraction (SPE) system (Caliper Corporation, Hopkington, MA), as depicted by Vanderford and Snyder (2006). Briefly, the $6 \mathrm{~mL}, 500 \mathrm{mg}$ hydrophilic-lipophilic balance (HLB) glass cartridges (Waters Corporation, Milford, MA) were preconditioned in the following order: $5 \mathrm{~mL}$ of MTBE, $5 \mathrm{~mL}$ of methanol, and $5 \mathrm{~mL}$ of deionized water. $500 \mathrm{~mL}$ of samples, spiked with the addition of standards for internal calibration, were loaded onto the cartridges at $15 \mathrm{~mL} \mathrm{~min}^{-1}$ in duplicate, after which the cartridges were rinsed with $5 \mathrm{~mL}$ of deionized pure water, and then dried with a steam of air for $50 \mathrm{~min}$. The cartridges were eluted with $5 \mathrm{~mL}$ of methanol, followed by $5 \mathrm{~mL}$ of $1 / 9(v / v)$ methanol/MTBE. The eluted solution was concentrated in a water bath at $40^{\circ} \mathrm{C}$ with a gentle stream of air to a final volume of $500 \mu \mathrm{L}$, which was a concentration factor of 1000. The levels of pharmaceuticals and their metabolites were then measured using a Water 2695 Separations Module (Waters, Milford, MA) coupled with a Micromass Quattro Micro triple quadrupole tandem mass spectrometer (Micromass, Manchester, UK) in electrospray ionization mode (ESI). A $20 \mu \mathrm{L}$ sample loop and $150 \times 2.1 \mathrm{~mm}$ SunFire C18 column with a particle size of $3.5 \mu \mathrm{m}$ (Waters, Milford, MA) was employed for analyte separation. A binary gradient, consisting of $0.1 \%$ formic acid (eluent $\mathrm{A}$ ) and $100 \%$ acetonitrile (eluent B), was used at a flow rate of $0.2 \mathrm{~mL} \mathrm{~min}^{-1}$. Selected PPCPs and their metabolites was analyzed using two different gradients. The gradient used for the PPCPs and most of the metabolites was: gradient with $15 \%$ of B was held for $4 \mathrm{~min}$, increased linearly to $80 \%$ for 
Table 1. Tested parent compounds and metabolites.

\begin{tabular}{|c|c|c|c|c|c|}
\hline Analytes & Uses & Structure & $p K_{\mathrm{a}}^{\mathrm{a}}$ & $\log K_{\text {ow }}{ }^{\mathrm{a}}$ & $\begin{array}{l}\log D^{\mathrm{a}} \\
\text { at } \mathrm{pH} 7\end{array}$ \\
\hline Acetaminophen & Analgesic & & 9.46 & 0.91 & 0.91 \\
\hline Glimepiride & Anticholesterol & & 4.32 & 3.12 & 2.18 \\
\hline $\begin{array}{l}\text { tri(2-chloroethyl) phosphate } \\
\text { (TCEP) }\end{array}$ & Flame retardant & & N.E & 2.11 & 2.11 \\
\hline Carbamazepine (CBZ) & Anticonvulsant & & N.E & 2.77 & 2.77 \\
\hline CBZ-EP & $\begin{array}{l}\text { Carbamazepine } \\
\text { metabolite }\end{array}$ & & N.E. & 1.97 & 1.97 \\
\hline $\mathrm{CBZ}-2 \mathrm{OH}$ & $\begin{array}{l}\text { Carbamazepine } \\
\text { metabolite }\end{array}$ & & 9.3 & 2.66 & 2.66 \\
\hline $\mathrm{CBZ}-3 \mathrm{OH}$ & $\begin{array}{l}\text { Carbamazepine } \\
\text { metabolite }\end{array}$ & & 9.46 & 2.66 & 2.66 \\
\hline CBZ-10OH & $\begin{array}{l}\text { Carbamazepine } \\
\text { metabolite }\end{array}$ & & 14.1 & 1.73 & 1.73 \\
\hline Sulfamethoxazole & Antibiotic & & 6.16 & 0.79 & 0.14 \\
\hline $\mathrm{N}^{4}$-acetylsulfamethoxazole & $\begin{array}{l}\text { Sulfamethoxazole } \\
\text { metabolite }\end{array}$ & & 5.88 & 0.86 & 0.1 \\
\hline Diclofenac & Analgesic & & 4.00 & 4.26 & 0.96 \\
\hline
\end{tabular}


Table 1. Continued.

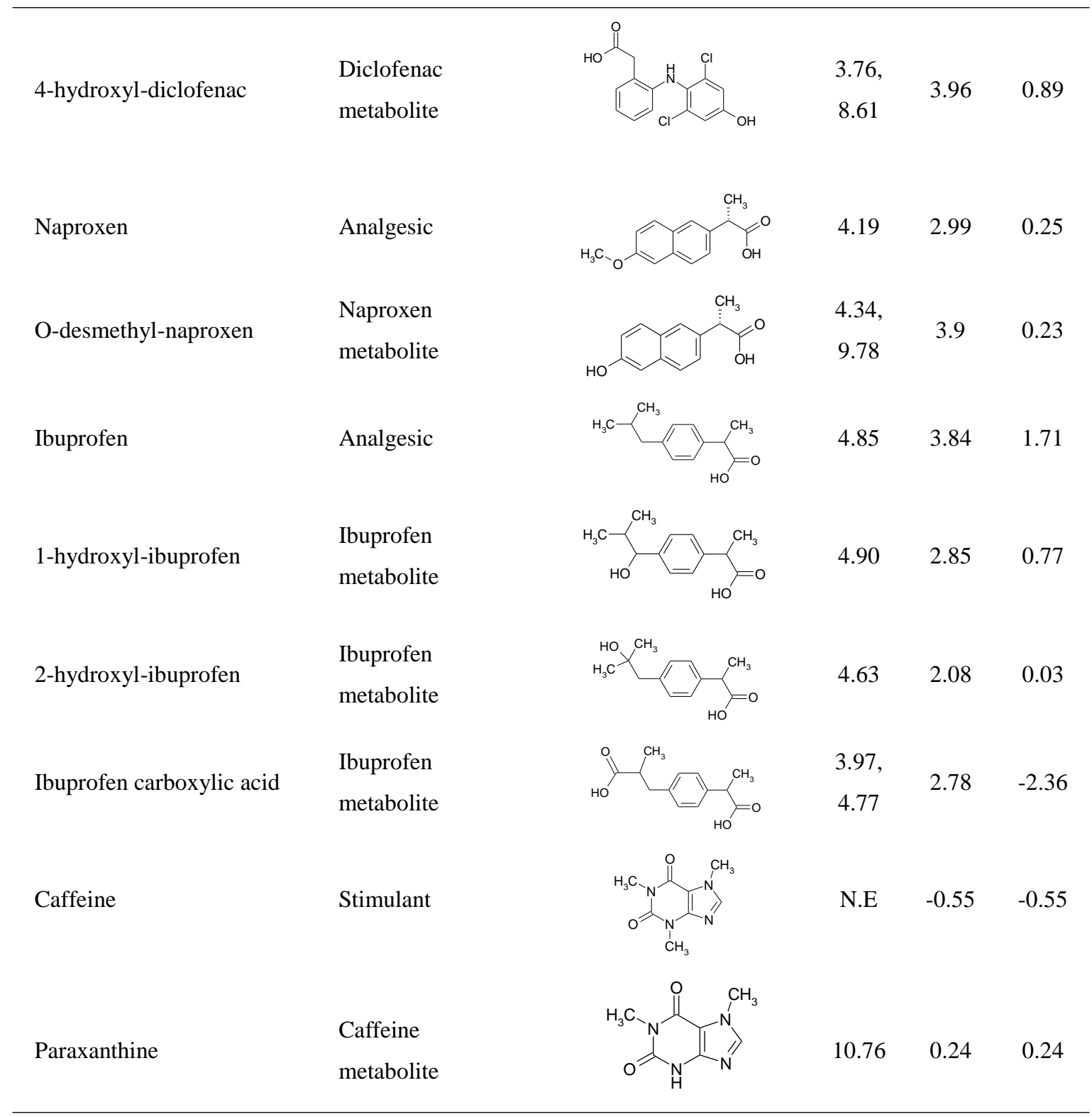

${ }^{a} \log P, \log D$, and $p K_{\mathrm{a}}$ value were calculated from the Software Calculator Plugins.

${ }^{\mathrm{b}}$ N.E: nonexistent at $\mathrm{pH}$ range $1-14$.

$6 \mathrm{~min}$, held for 3 min with $80 \%$ of B and then linearly increased to $100 \%$ for $7 \mathrm{~min}$. The gradient used for the carbamazepine metabolites was: gradient with $10 \%$ of B increased linearly to $40 \%$ for $15 \mathrm{~min}$, increased linearly to $90 \%$ for $10 \mathrm{~min}$, and held until $30 \mathrm{~min}$ (Kang et al., 2008). A $5 \mathrm{~min}$ equilibration step with gradient of $10 \% \mathrm{~B}$ was used at the beginning of each run. Detail LC-MS/MS analysis condition and analytical parameters of target compounds are shown in Table 2.

\subsection{Molecular orbital calculations}

Molecular orbital were calculated single determinant (Hartree-Fock) for optimization bearing the minimum energy obtained at the AM1 level. All semi-empirical calculations to obtain the point charge and electron density for pharmaceuticals and metabolites were performed in MO-G with a SCIGRESS package version 7.7 (Fujitsu Co. Ltd.) (Watanabe et al., 2003). 
Table 2. Analytical parameters of selected compounds (MDL: method detection limit; RL: reporting limit).

\begin{tabular}{|c|c|c|c|c|c|c|c|}
\hline Compound & $\begin{array}{l}\text { Retention } \\
\text { time (min) }\end{array}$ & $\begin{array}{c}\text { Cone } \\
\text { voltage }(\mathrm{V})\end{array}$ & $\begin{array}{c}\text { Collision } \\
\text { energy (eV) }\end{array}$ & $\begin{array}{c}\text { Parent } \\
\text { ion }(m / z)\end{array}$ & $\begin{array}{l}\text { Daughter } \\
\text { ion }(m / z)\end{array}$ & $\begin{array}{r}\mathrm{MDL} \\
\left(\operatorname{ng~L}^{-1}\right)\end{array}$ & $\begin{array}{r}\mathrm{RL} \\
\left(\mathrm{ng} \mathrm{L^{-1 }}\right)\end{array}$ \\
\hline \multicolumn{8}{|l|}{ ESI negative } \\
\hline Diclofenac & 15.53 & 15 & 10 & 294 & 249 & 1.3 & 3.9 \\
\hline Diclofenac-d ${ }_{4}$ & 11.23 & 15 & 12 & 298 & 254 & & \\
\hline 4-OH-DCF & 13.70 & 20 & 12 & 310 & 266 & 5.1 & 15.3 \\
\hline Ibuprofen & 15.70 & 15 & 8 & 205 & 161 & 1.2 & 3.6 \\
\hline Ibuprofen- $\mathrm{d}_{3}$ & 11.63 & 15 & 8 & 208 & 164 & & \\
\hline IBU-1OH & 12.87 & 15 & 7 & 221 & 177 & 5.8 & 17.5 \\
\hline IBU-2OH & 12.23 & 17 & 7 & 221 & 177 & 0.9 & 2.7 \\
\hline IBU-CA & 12.27 & 12 & 5 & 235 & 191 & 2.3 & 6.8 \\
\hline Naproxen & 9.84 & 10 & 8 & 229 & 185 & 3.3 & 10.0 \\
\hline Naproxen- $\mathrm{d}_{3}$ & 9.83 & 10 & 6 & 233 & 189 & & \\
\hline O-desmethyl-NPX & 8.10 & 15 & 12 & 215 & 171 & 1.2 & 3.5 \\
\hline N-acetyl-SMZ & 7.71 & 30 & 13 & 294 & 198 & 0.9 & 2.7 \\
\hline TCEP & 9.12 & 30 & 16 & 285 & 161 & 7.9 & 23.8 \\
\hline \multicolumn{8}{|l|}{ ESI positive } \\
\hline Acetaminophen & 3.98 & 28 & 17 & 152 & 110 & 0.5 & 1.5 \\
\hline Acetaminophen- $\mathrm{d}_{4}$ & 3.98 & 28 & 17 & 156 & 114 & & \\
\hline Glimepiride & 11.34 & 28 & 13 & 491 & 352 & 1.5 & 4.6 \\
\hline Sulfamethoxazole & 7.83 & 30 & 18 & 254 & 156 & 0.6 & 1.7 \\
\hline Sulfamethoxazole- $\mathrm{d}_{4}$ & 7.80 & 25 & 15 & 258 & 160 & & \\
\hline Caffeine & 6.11 & 35 & 20 & 195 & 138 & 1.5 & 4.6 \\
\hline Paraxanthine & 2.72 & 30 & 22 & 181 & 124 & 9.3 & 27.9 \\
\hline Paraxanthine- $d_{3}$ & 2.72 & 30 & 22 & 184 & 124 & & \\
\hline Carbamazepine & 19.31 & 35 & 18 & 237 & 194 & 0.7 & 2.1 \\
\hline Carbamazepine- $\mathrm{d}_{10}$ & 8.74 & 35 & 18 & 247 & 204 & & \\
\hline CBZ-EP & 15.64 & 28 & 24 & 253 & 180 & 1.2 & 3.6 \\
\hline CBZ-2OH & 14.34 & 35 & 20 & 253 & 210 & 13.0 & 3.9 \\
\hline CBZ-3OH & 15.78 & 35 & 20 & 253 & 210 & 1.5 & 4.5 \\
\hline CBZ-10OH & 13.63 & 30 & 20 & 255 & 194 & 0.2 & 0.5 \\
\hline
\end{tabular}

Table 3. Concentrations of selected PPCPs in WWTPs and wetlands.

\begin{tabular}{|c|c|c|c|c|c|c|c|c|c|}
\hline \multirow[t]{2}{*}{ PPCPs } & \multicolumn{2}{|c|}{$\begin{array}{c}\text { Gwangju Primary } \\
\text { WWTP }\end{array}$} & \multicolumn{2}{|c|}{$\begin{array}{c}\text { Gwangju Secondary } \\
\text { WWTP }\end{array}$} & \multicolumn{5}{|c|}{ Damyang WWTP and Constructed wetlands } \\
\hline & $\begin{array}{l}\text { WWTP } \\
\text { influent } \\
\left(\mathrm{ng} \mathrm{L}^{-1}\right)\end{array}$ & $\begin{array}{l}\text { WWTP } \\
\text { effluent } \\
\left(n g \mathrm{~L}^{-1}\right)\end{array}$ & $\begin{array}{l}\text { WWTP } \\
\text { influent } \\
\left(n g \mathrm{~L}^{-1}\right)\end{array}$ & $\begin{array}{l}\text { WWTP } \\
\text { effluent } \\
\left(\mathrm{ng} \mathrm{L}^{-1}\right)\end{array}$ & $\begin{array}{l}\text { WWTP } \\
\text { influent } \\
\left(n g L^{-1}\right)\end{array}$ & $\begin{array}{l}\text { WWTP } \\
\text { effluent } \\
\left(n g L^{-1}\right)\end{array}$ & $\begin{array}{l}\text { Acorus } \\
\text { wetland } \\
\left(n g L^{-1}\right)\end{array}$ & $\begin{array}{r}\text { Typha } \\
\text { wetland } \\
\left(n g L^{-1}\right)\end{array}$ & $\begin{array}{l}\text { Wetland } \\
\text { effluent } \\
\left(n g L^{-1}\right)\end{array}$ \\
\hline Caffeine & 72471.2 & $<4.6$ & 45457.0 & 1857.8 & 36880.6 & $<4.6$ & $<4.6$ & 47.0 & $<4.6$ \\
\hline Carbamazepine & 2085.4 & 108.3 & 1668.8 & 362.8 & 844.5 & 417.2 & 387.1 & 161.4 & 268.3 \\
\hline Sulfamethoxazole & 6048.6 & 88.8 & 8092.9 & 70.7 & 409.7 & 27.4 & 17.9 & 7.4 & 17.4 \\
\hline Acetaminophen & 162159.9 & 1705.8 & 227705.4 & 180.5 & 194586.8 & 189.7 & 354.8 & 549.5 & 349.6 \\
\hline Ibuprofen & 2626.0 & $<3.6$ & 4576.5 & 166.6 & 1645.3 & 17.9 & 43.2 & 52.9 & 47.2 \\
\hline Naproxen & 1140.5 & $<10.0$ & 1778.5 & 10.7 & 203.5 & $<10.0$ & 11.4 & $<10.0$ & $<10.0$ \\
\hline Diclofenac & 2673.5 & 111.7 & 2702.8 & $<3.8$ & 150.5 & 19.8 & 20.15 & $<3.8$ & 8.9 \\
\hline Glimepiride & 18895.3 & 197.4 & 40338.6 & 86.6 & 36.8 & 12.3 & 11.3 & $<4.6$ & 14.4 \\
\hline TCEP & 6011.8 & 320.3 & 4774.7 & $<23.8$ & 2608 & 340.6 & 277.85 & 186.35 & 268.4 \\
\hline
\end{tabular}


Table 4. Concentrations of parent pharmaceuticals and their metabolites in WWTPs and wetlands.

\begin{tabular}{lrrrrrrrrr}
\hline $\begin{array}{l}\text { Parent compounds and } \\
\text { their metabolites }\end{array}$ & \multicolumn{2}{c}{$\begin{array}{c}\text { Gwangju Primary } \\
\text { WWTP }\end{array}$} & $\begin{array}{r}\text { Gwangju Secondary } \\
\text { WWTP }\end{array}$ & \multicolumn{3}{c}{ Damyang WWTP and Constructed wetlands } \\
& $\begin{array}{r}\text { WWTP } \\
\text { influent } \\
\left(\mathrm{ng} \mathrm{L}^{-1}\right)\end{array}$ & $\begin{array}{r}\text { WWTP } \\
\text { effluent } \\
\left(\mathrm{ng} \mathrm{L}^{-1}\right)\end{array}$ & $\begin{array}{r}\text { WWTP } \\
\text { influent } \\
\left(\mathrm{ng} \mathrm{L}^{-1}\right)\end{array}$ & $\begin{array}{r}\text { WWTP } \\
\text { effluent } \\
\left(\mathrm{ng} \mathrm{L}^{-1}\right)\end{array}$ & $\begin{array}{r}\text { WWTP } \\
\text { influent } \\
\left(\mathrm{ng} \mathrm{L}^{-1}\right)\end{array}$ & $\begin{array}{r}\text { WWTP } \\
\text { effluent } \\
\left(\mathrm{ng} \mathrm{L}^{-1}\right)\end{array}$ & $\begin{array}{r}\text { Acorus } \\
\text { wetland } \\
\left(\mathrm{ng} \mathrm{L}^{-1}\right)\end{array}$ & $\begin{array}{r}\text { Typha } \\
\text { wetland } \\
\left(\mathrm{ng} \mathrm{L}^{-1}\right)\end{array}$ & $\begin{array}{r}\text { Wetland } \\
\text { effluent } \\
\left(\mathrm{ng} \mathrm{L}^{-1}\right)\end{array}$ \\
\hline Caffeine & 72471.2 & $<4.6$ & 45457.0 & $<4.6$ & 36880.6 & $<4.6$ & $<4.6$ & 47.0 & $<4.6$ \\
Paraxanthine & 8215.3 & 33.9 & 10442.1 & $<27.9$ & 3222.3 & $<27.9$ & $<27.9$ & $<27.9$ & $<27.9$ \\
\hline Sulfamethoxazole & 6048.6 & 88.8 & 8092.9 & 166.6 & 409.7 & 27.4 & 17.9 & 7.4 & 17.4 \\
N-acetyl-SMZ & 5224.8 & 64.5 & 6224.2 & 72.4 & 152.6 & 4.9 & $<2.7$ & $<2.7$ & 5.3 \\
\hline Naproxen & 1140.5 & $<10.0$ & 1778.5 & 10.7 & 203.5 & $<10.0$ & 11.4 & $<10.0$ & $<10.0$ \\
O-desmethyl-NPX & 191.5 & 31.7 & 125.0 & 31.1 & 245.0 & 9.3 & $<3.5$ & $<3.5$ & 7.75 \\
\hline Diclofenac & 2673.5 & 111.7 & 2702.8 & 86.6 & 150.5 & 19.8 & 20.15 & $<3.8$ & 8.9 \\
4-OH-DCF & 530.6 & 582.1 & 396.0 & 504.6 & 212.0 & 40.2 & 21.15 & $<15.3$ & $<15.3$ \\
\hline
\end{tabular}

\section{Results and discussion}

\subsection{Removal of pharmaceuticals and personal care products in WWTPs and wetlands}

Removal of PPCPs in municipal wastewater treatment plants and constructed wetlands were investigated and summarized by comparing the concentrations of PPCPs in the influent and final effluent of each WWTP in Table 3. Unfortunately, the contribution of different transport mechanisms such as biodegradation, adsorption to sludge and sediments, and oxidation during disinfection was not considered here. Gwangju WWTP was found as a major source, releasing tons of micropollutants to the Yeongsan River water, and, the concentrations of PPCPs in Gwangju WWTPs $\left(\sim \mu \mathrm{gL}^{-1}\right)$ were generally much higher than in Damyang WWTP $\left(\sim \mathrm{ng} \mathrm{L}^{-1}\right)$, presumably resulting from the dense populations in Gwangju area.

Particularly, high concentrations of caffeine and acetaminophen in WWTP influents reflect frequent use and ingestion of those compounds in this urban area. Most of PPCPs exhibited high removal efficiency (>90\%) during the WWTPs processes, except for carbamazepine removal in Gwangju secondary WWTP (removal efficiency at $74 \%$ ). After discharge of WWTP effluent into connected constructed wetlands, levels of some PPCPs (carbamazepine, sulfamethoxaolze, diclofenac, and TCEP) slightly decreased. This result indicates that operation of wastewater stabilization ponds or wetlands would be helpful to prevent release of micropollutants into surface water. Our research group has previously been studied the Damyang constructed wetlands with respect to the control of organic micropollutants, and, reported the efficiency of wetland treatments depending on the wetland characteristics and properties of micropollutants (Park et al., 2009). Many other studies have also been supported the necessity of additional wetland treatments for mi- cropollutants control (Matamoros and Bayona, 2006; Conkle et al., 2008).

\subsection{Transformation of pharmaceuticals and formation of metabolites in WWTPs}

Table 4 shows occurrence of parent pharmaceuticals and their metabolites in WWTPs and wetlands system. In the WWTPs influent, most metabolites were detected at high level of concentrations with range of $100 \sim 10000 \mathrm{ng} \mathrm{L}^{-1}$ compared to WWTP effluents, indicating dominant transformation pathway of metabolite resulting from human body rather than microbial transformation. However, after passing the WWTPs, concentrations of most metabolites were observed higher than that of parent compounds, indicating the structural stability of the metabolites during the WWTP process relative to their parent compounds. The stability of metabolites may be related to the difference of the $\log D$ value between parent pharmaceutical compounds and pharmaceutical metabolites. As pharmaceuticals transformed into their metabolites, their $\log D$ value at $\mathrm{pH} 7$ slightly decreased (Table 1). Considering the dominant removal mechanism of micropollutants in WWTP process (i.e., sorption and biodegradation), decrease of $\log D$ may result in the reduction of sorption of pharmaceutical metabolites on the sludge surface. Consequently, pharmaceutical metabolites would be detected at higher levels than parent compounds in WWTP effluents.

In case of sulfamethoxazole metabolite, even though the concentrations of $\mathrm{N}$-acetyl-sulfamethoxazole were low enough in wastewater effluents, by considering retransformation of acetylated metabolite back into its parent compound, $\mathrm{N}$-acetyl-sulfamethoxazole should be assumed as a pharmaceutically active parent compound (Göbel et al., 2005). And based on this reason, monitoring of $\mathrm{N}$-acetyl-sulfamethoxazole is important and necessary 

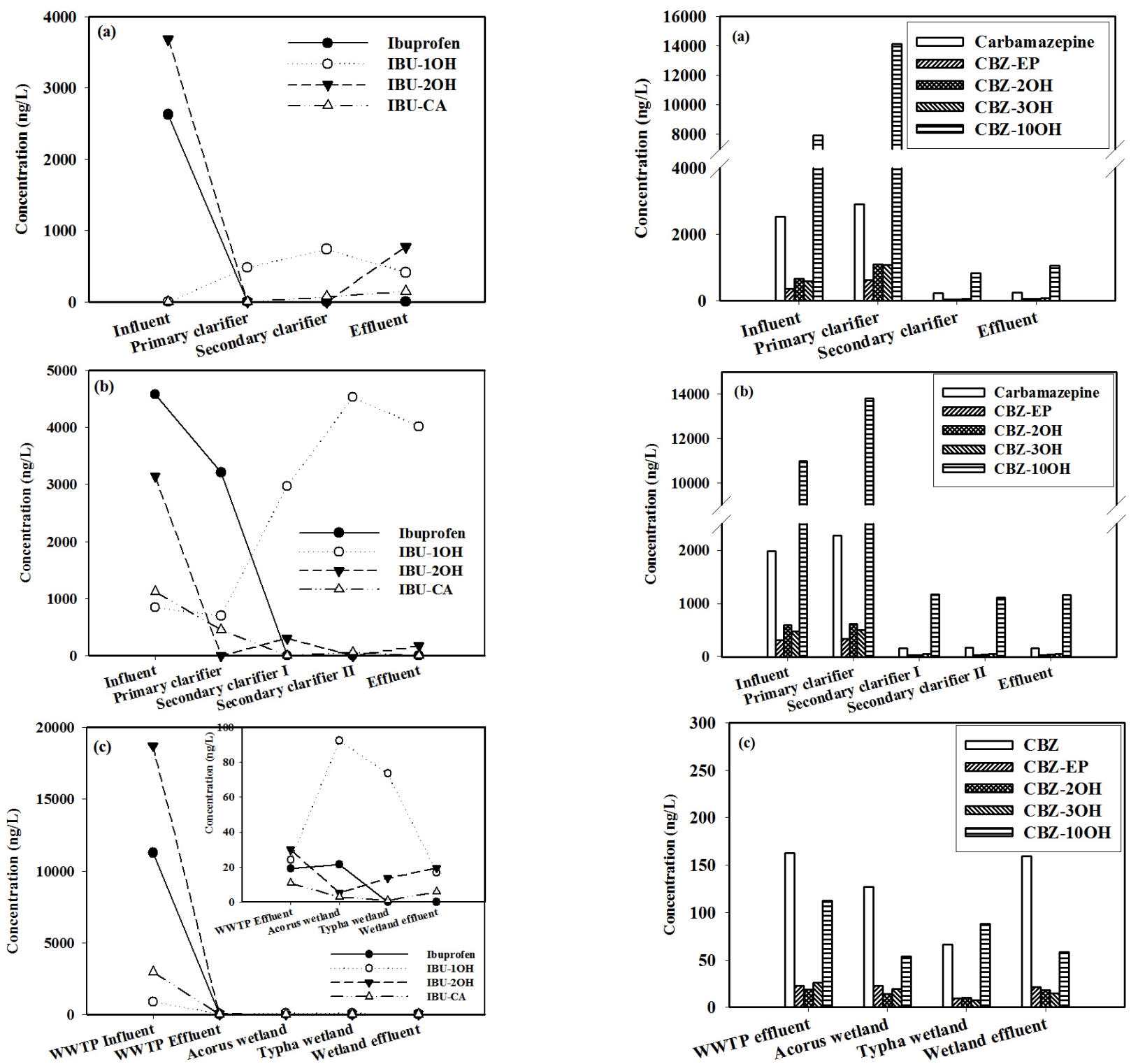

Figure 1. Transformation of ibuprofen in different WWTPs system: (a) Gwangju primary WWTP, (b) Gwangju secondary WWTP, (c) Damyang WWTP and constructed wetlands.

for the effective control of micropollutants in aquatic environment.

During the engineered constructed wetland treatments, there was no specific change of pharmaceutical metabolites in exception with ibuprofen metabolites. As can be seen in Fig. 1, ibuprofen was differently transformed depending on the treatment process. In WWTPs influent, 2-hydroxyibuprofen, the well-known human metabolite of ibuprofen was dominant, whereas, after the activated sludge treatment, concentrations of 1-hydroxyibuprofen indicate the highest level in all WWTPs and wetlands. Significant formation of 1-hydroxyibuprofen in WWTPs might be possibly explained by preferential microbial metabolism in ac-

tivated sludge treatment process. In the additional experimental results conducted in river waters, completely different composition of ibuprofen metabolites was observed. 2hydroxy-ibuprofen was found to be dominant in both river waters, Yeongsan River and Seomjin River (data are not shown). This might infer that 2-hydroxyibuprofen is much more persistent and stable than 1-hydroxyibuprofen and even than parent compound, ibuprofen, as previously mentioned by Weigel et al. (2004).

In contrast, carbamazepine did not exhibit any change in transformation behavior during WWTPs and wetland treatments (Fig. 2). All the selected carbamazepine metabolites, 10,11-epoxy-carbamazepine, 2-hydroxycarbamazepine, 
Table 5. Calculations of frontier electron density for carbamazepine.

\begin{tabular}{lccccc}
\hline $\begin{array}{l}\text { Atom } \\
\text { List }\end{array}$ & $\begin{array}{c}\text { HOMO } \\
\text { Density }\end{array}$ & $\begin{array}{c}\text { Nucleophilic Frontier } \\
\text { Density }\end{array}$ & $\begin{array}{c}\text { Electrophilic Frontier } \\
\text { Density }\end{array}$ & $\begin{array}{c}\text { Radical Frontier } \\
\text { Density }\end{array}$ & $\begin{array}{c}\text { LUMO } \\
\text { Density }\end{array}$ \\
\hline $\mathrm{C}_{1}$ & 0.148 & 0.202 & 0.215 & 0.208 & 0.131 \\
$\mathrm{C}_{2}$ & 0.119 & 0.252 & 0.175 & 0.214 & 0.169 \\
$\mathrm{C}_{3}$ & 0.064 & 0.222 & 0.108 & 0.165 & 0.136 \\
$\mathrm{C}_{4}$ & 0.118 & 0.113 & 0.184 & 0.148 & 0.057 \\
$\mathrm{C}_{5}$ & 0.046 & 0.201 & 0.088 & 0.145 & 0.090 \\
$\mathrm{C}_{6}$ & 0.067 & 0.113 & 0.136 & 0.124 & 0.049 \\
$\mathrm{~N}_{7}$ & 0.074 & 0.003 & 0.211 & 0.107 & 0.000 \\
$\mathrm{C}_{8}$ & 0.039 & 0.141 & 0.080 & 0.111 & 0.054 \\
$\mathrm{C}_{9}$ & 0.010 & 0.117 & 0.036 & 0.076 & 0.030 \\
$\mathrm{C}_{10}$ & 0.068 & 0.214 & 0.111 & 0.163 & 0.133 \\
$\mathrm{C}_{11}$ & 0.012 & 0.088 & 0.044 & 0.066 & 0.013 \\
$\mathrm{C}_{12}$ & 0.046 & 0.094 & 0.117 & 0.105 & 0.047 \\
$\mathrm{C}_{13}$ & 0.024 & 0.048 & 0.076 & 0.062 & 0.007 \\
$\mathrm{C}_{14}$ & 0.111 & 0.129 & 0.173 & 0.151 & 0.072 \\
$\mathrm{C}_{15}$ & 0.016 & 0.043 & 0.078 & 0.060 & 0.010 \\
$\mathrm{C}_{16}$ & 0.012 & 0.010 & 0.021 & 0.016 & 0.000 \\
$\mathrm{~N}_{17}$ & 0.007 & 0.002 & 0.072 & 0.037 & 0.000 \\
$\mathrm{O}_{18}$ & 0.018 & 0.002 & 0.064 & 0.033 & 0.000 \\
$\mathrm{H}_{19}$ & 0.000 & 0.001 & 0.001 & 0.001 & 0.000 \\
$\mathrm{H}_{20}$ & 0.000 & 0.000 & 0.001 & 0.001 & 0.000 \\
$\mathrm{H}_{21}$ & 0.001 & 0.002 & 0.002 & 0.002 & 0.001 \\
$\mathrm{H}_{22}$ & 0.002 & 0.001 & 0.003 & 0.002 & 0.000 \\
\hline
\end{tabular}<smiles>Cc1cccc2c1C=Cc1ccccc1N2C(N)=O</smiles>

Figure 3. Structure of carbamazepine.

3-hydroxycarbamazepine and 10-hydroxycarbamazepine was detected in influents, effluents of WWTPs and wetlands. Even though the levels of 10,11-epoxy-carbamazepine was low, the eco-toxicological effect of CBZ-EP on the environment is worthy of further examination due to its pharmaceutically active property like its parent compound, carbamazepine. The most dominant carbamazepine metabolite was 10-hydroxy-carbamazepine. The predominant formation of CBZ-10OH might be due to the different distribution of electron density of atoms in carbamazepine.

\subsection{Effect of electron density on transformation of carbamazepine into metabolites}

In previous studies, electron density distribution of chemicals has been used to find the initial positions of $\mathrm{OH}$ radical attack in oxidation (Watanabe et al., 2003; Jung et al., 2010; Heimstad et al., 2009). A higher electron density indicates more electrons in the bonds, resulting in electrophilic reaction (Horikoshi et al., 2004; Kaneco et al., 2006). In this study, electron density of pharmaceutical was examined to find the initial transformation position in various transformation mechanisms including biological process and photochemical oxidations. In previous study, Park et al. (2009) suggested that hydrolysis reaction at the amide and urea functional groups may lead to the biological transformation of carbamazepine. Frontier electron density of carbamazepine calculated by MOPAC, Scigress software is shown in Table 5. Radical frontier density, the averaged value of nucleophilic frontier density and electrophilic frontier density, are used in this study. Based on the electron density of carbamazepine, the carbon bonds between $C_{1}$ and $C_{2}$ showed the largest frontier electron density ( 0.208 and 0.214 , respectively). This electron rich carbon bond of the olefin structure may provide the initial position of oxidation. Prevalent occurrence of specific carbamazepine metabolites such as CBZ-EP, CBZ$10 \mathrm{OH}$, and CBZ-DiOH in environment are presumably related with this oxidation pathway. However, other metabolites were difficult to find a relationship between transformation and electron density. The reason for this low relationship is thought that there might be some other different preferred transformation pathways depending on the intrinsic property of chemicals rather than electron density derived transformation. However, electron density of chemicals is still believed as a key parameter to elucidate unknown pathway in various processes, especially in oxidation process. 


\section{Conclusions}

Removal and transformation of pharmaceuticals in WWTPs and constructed wetlands were extensively investigated in this study. Pharmaceuticals were effectively removed by different WWTP processes and wetlands. From this study, the additional operation of wastewater management wetlands was encouraged to prevent direct discharge of micropollutants into surface waters. And additionally, pharmaceutical metabolites were found to be more stable than the parent compounds during WWTP processes due to the lower $\log D$ value of metabolites than parent compounds. Different transformation pattern of pharmaceuticals was also observed, especially in transformation of ibuprofen. 1-hydroxyibuprofen was dominantly formed during biological treatment in WWTP, indicating preferential biotransformation of ibuprofen. At last, electron density of carbamazepine was examined to elucidate the transformation pathway. The electron rich $\mathrm{C}_{1}=\mathrm{C}_{2}$ bond in olefin structure of carbamazepine was revealed as an initial transformation position.

Acknowledgements. This research was supported by the National Research Foundation of Korea (NRF) grant funded by the Korea government (MEST) (No. 2012047029).

Edited by: I. S. Kim

\section{References}

Benotti, M. J., Trenholm, R. A., Vanderford, B. J., Holady, J. C., Stanford, B. D., and Snyder, S. A.: Pharmaceuticals and endocrine disrupting compounds in U.S. drinking water, Environ. Sci. Technol., 43, 597-603, 2009.

Conkle, J. L., White, J. R., and Metcalf, C. D.: Reduction of pharmaceutically active compounds by a lagoon wetland wastewater treatment system in Southeast Louisiana, Chemosphere, 73, 1741-1748, 2008.

Göbel, A., Thomsen, A., McArdell, C. A., Joss, A., and Giger, W.: Occurrence and sorption behavior of sulfonamides, macrolides, and trimethoprim in activated sludge treatment, Environ. Sci. Technol., 39, 3981-3989, 2005.

Heimstad, E. S., Bastos, P. M., Eriksson, J., Bergman, A., and Harju, M.: Quantitative structure - Photodegradation relationships of polybrominated diphenyl ethers, phenoxyphenols and selected organochlorines, Chemosphere, 77, 914-921, 2009.

Horikoshi, S., Tokunaga, A., Hidaka, H., and Serpone, N.: Environmental remediation by an integrated microwave/UV illumination method: VII. Thermal/non-thermal effects in the microwaveassisted photocatalyzed mineralization of bisphenol-A, J. Photoch. Photobio. A, 162, 33-40, 2004.

Jung, Y. J., Oh, B. S., Kim, K. S., Koga, M., Shinohara, R., and Kang, J. W.: The degradation of diethyl phthalate (DEP) during ozonation: oxidation by-products study, J. Water Health., 8, 290298, 2010.
Kaneco, S., Katsumata, H., Suzuki, T., and Ohta, K.: Titanium dioxide mediated photocatalytic degradation of dibutyl phthalate in aqueous solution - kinetics, mineralization and reaction mechanism, Chem. Eng. J., 125, 59-66, 2006.

Kang, S.-I., Kang, S.-Y., and Hur, H.-G.: Identification of fungal metabolites of anticonvulsant drug carbamazepine, Appl. Microbiol. Biotechnol., 79, 663-669, 2008.

Kim, S. D., Cho, J., Kim, I. S., Vanderford, B. J., and Snyder, S. A.: Occurrence and removal of pharmaceuticals and endocrine disruptors in South Korean surface, drinking, and waste waters, Water Res., 41, 1013-1021, 2007.

Lee, E., Lee, S., Kim, Y., Huh, Y.-J., Kim, K.-S., Lim, B.-J., and Cho, J.: Wastewater Treatment Plant: Anthropogenic Micropollutant Indicators for Sustainable River Management, in: Encyclopedia of Sustainability Science and Technology, edited by: Meyers, R. A., Springer, 17, 11911-11932, 2012.

Lee, S., Kang, S. I., Lim, J. L., Huh, Y. J., and Cho, J.: Evaluating controllability of pharmaceuticals and metabolites, in biologically-engineered processes, using corresponding octanolwater partitioning coefficient with consideration of ionizable functional groups, Ecol. Eng., 37, 1595-1600, 2011.

Lee, Y. and von Gunten, U.: Oxidative transformation of micropollutants during municipal wastewater treatment: Comparison of kinetic aspects of selective (chlorine, chlorine dioxide, ferrateVI, and ozone) and non-selective oxidants (hydroxyl radical), Water Res., 44, 555-566, 2010.

Matamoros, V. and Bayona, J. M.: elimination of pharmaceuticals and personal care products in subsurface flow constructed wetlands, Environ. Sci. Technol., 40, 5811-5816, 2006.

Park, N., Vanderford, B. J., Snyder, S. A., Sarp, S., Kim, S. D., and Cho, J.: Effective controls of micropollutants included in wastewater effluent using constructed wetlands under anoxic condition, Ecol. Eng., 35, 418-423, 2009.

Quintana, J. B., Weiss, S., and Reemtsma, T.: Pathways and metabolites of microbial degradation of selected acidic pharmaceutical and their occurrence in municipal wastewater treated by a membrane bioreactor, Water Res., 39, 2654-2664, 2005.

Rosal, R., Rodríguez, A., Perdigón-Melón, J. A., Petre, A., GarcíaCalvo, E., Gómez, M. J., Agüera, A., and Fernández-Alba, A. R.: Occurrence of emerging pollutants in urban wastewaterand their removal through biological treatment followed by ozonation, Water Res., 44, 578-588, 2010.

Snyder, S. A., Westerhoff, P., Yoon, Y., and Sedlak, D. L.: pharmaceuticals, personal care products, and endocrine disruptors in water: implications for the water industry, Environ. Eng. Sci., 20, 449-469, 2003.

Stumpf, M., Ternes, T. A., Haberer, K., and Baumann, W.: Isolation of ibuprofen-metabolites and their importance as pollutants of the aquatic environment, Vom Wasser, 91, 291-303, 1998.

Ternes, T. A.: Occurrence of drugs in German sewage treatment plants and rivers, Water. Res., 32, 3245-3260, 1998.

Vanderford, B. J. and Snyder, S. A.: Analysis of pharmaceuticals in water by isotope dilution liquid chromatography/tandem mass spectrometry, Environ. Sci. Technol., 40, 7312-7320, 2006.

Watanabe, N., Horikoshi, S., Kawabe, H., Sugie, Y., Zhao, J., and Hidaka, H.: Photodegradation mechanism for bisphenol A at the $\mathrm{TiO}_{2} / \mathrm{H}_{2} \mathrm{O}$ interfaces, Chemosphere, 52, 851-859, 2003. 
Weigel, S., Berger, U., Jensen, E., Kallenborn, R., Thoresen, H., and Hühnerfuss, H.: Determination of selected pharmaceuticals and caffeine in sewage and seawater from Troms $\varnothing /$ Norway with emphasis on ibuprofen and its metabolites, Chemosphere, 56, 583$592,2004$.
Yoon, Y., Ryu, J., Oh, J., Choi, B. G., and Snyder, S. A.: Occurrence of endocrine disrupting compounds, pharmaceuticals, and personal care products in the Han River (Seoul, South Korea), Sci. Total Environ., 408, 636-643, 2010. 